\title{
Clonidine-induced dilutional hyponatraemia
}

\author{
A. W. BURROWS* \\ B.M., M.R.C.P.
}

\author{
B. GRIBBIN \\ M.D., M.R.C.P.
}

Department of Medicine, Radcliffe Infirmary, Oxford

\begin{abstract}
Summary
A patient with a dilutional hyponatraemia induced by clonidine is decribed.

\section{Introduction}

An inappropriate secretion of antidiuretic hormone (ADH) (Bartter and Schwartz, 1967) has been associated with the administration of a variety of different drugs (Moses and Miller, 1974).
\end{abstract}

\section{Case report}

A 65-year-old woman was admitted with a 3-week history of persistent vomiting. She had been treated for several years for hypertension with clonidine $0.2 \mathrm{mg}$ thrice daily, and chlorthalidone $50 \mathrm{mg}$ twice daily. Initial investigations showed: serum sodium $131 \mathrm{mmol} / 1$, potassium $2.6 \mathrm{mmol} / \mathrm{l}$, chloride 90 $\mathrm{mmol} / \mathrm{l}$, bicarbonate $34 \mathrm{mmol} / \mathrm{l}$, urea $7 \mathrm{mmol} / \mathrm{l}$. She was treated with intravenous isotonic saline and potassium supplements and her vomiting ceased after 3 days. She was found to have an Escherichia coli urinary tract infection and was discharged from hospital taking the antihypertensive drugs and trimethoprim/sulphamethoxazole.

Nine days later she was readmitted after further nausea and vomiting. On admission, the patient's level of consciousness was normal but later she became confused and disorientated. There were no clinical signs of dehydration. The course of antibacterial therapy had been completed, and the antihypertensive drugs were stopped on admission. Serum electrolyte values on this occasion were: sodium $118 \mathrm{mmol} / 1$, potassium $2.7 \mathrm{mmol} / 1$, chloride $72 \mathrm{mmol} / \mathrm{l}$, bicarbonate $31 \mathrm{mmol} / 1$, and urea $5 \cdot 7$ $\mathrm{mmol} / \mathrm{l}$. The serum osmolality was $253 \mathrm{mosmol} / \mathrm{kg}$ and urine osmolality $659 \mathrm{mosmol} / \mathrm{kg}$ and the urinary sodium excretion was $198 \mathrm{mmol} / 24 \mathrm{hr}$. There was no evidence of a persisting urinary tract infection and adrenocortical insufficiency was excluded by a normal short tetracosactrin test (basal plasma cortisol $395 \mathrm{mmol} / \mathrm{l}$ rising to $1130 \mathrm{mmol} / \mathrm{l}$ at 30 min after intramuscular injection of $0.25 \mathrm{mg}$ of

* Present address: University Department of Medicine, The General Infirmary, Leeds LS1 3EX. tetracosactrin). Initially the patient received treat- $\bar{\omega}$ ment with intravenous saline and potassium supple=-O ments, but after evaluation of the above results? fluid intake was restricted to 1 litre/day. There waser a rapid improvement in the patient's confusion, ando over 7 days serum sodium rose to $140 \mathrm{mmol} / \mathrm{l}$ andw్ serum osmolality to $289 \mathrm{mosmol} / \mathrm{kg}$. After a further week fluid intake was increased with no clinical or biochemical deterioration, and there was a normalo response to a fluid challenge.

Further investigations were instituted to determine the cause of the apparent inappropriate ADH secretion. There was no evidence of malignancy or other disease in the chest, gastrointestinal tract or $_{\overrightarrow{0}}$ brain. Pituitary and thyroid function was normal and urinary porphyrins were not detected.

In view of the possibility of a drug-induced effegto the patient's antihypertensive therapy was changed to methyldopa. In an attempt to clarify the positiono further and, if possible, to exclude an occult neo-年 plasm the patient agreed to be investigated again 0 several months later. During the intervening period, $\overrightarrow{\overrightarrow{0}}$ she had remained free of symptoms. Clonidine was 3 reintroduced as treatment for her hypertension and methyldopa was stopped. Within 3 days she experi-? enced nausea with vomiting and serum sodium fello from 139 to $129 \mathrm{mmol} / \mathrm{l}$. Blood urea and serum?. creatinine levels were normal throughout. Serum을 osmolality was reduced from 290 to $264 \mathrm{mosmol} / \mathrm{kg}$, while urine osmolality remained between 430 and $487 \mathrm{mosmol} / \mathrm{kg}$. At no stage in these investigations was glycosuria or amino-aciduria detected. After 을 stopping clonidine the patient rapidly recovered and $>$ has since remained free of any symptoms. Her blood pressure is now controlled with methyldopa.

\section{Discussion}

The authors consider that clonidine induced an inappropriate secretion of ADH in this patient. A

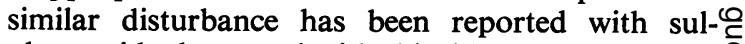
phonamide drugs and with thiazide duretics, both of which were being taken by this patient at some stage. However, as the typical dilutional hyponatraemia $\frac{0}{0}$ was produced rapidly on the reintroduction of $\frac{\mathrm{D}}{\mathrm{D}}$ 
clonidine alone, it appears that this drug can be implicated specifically and this has not been reported before. Although a urinary tract infection was present on the patient's first admission, this was not the case subsequently, and there was no evidence of any renal tubular disorder.

\section{References}

BARTTER, F.C. \& SchWARTz, W.B. (1967) The syndrome of inappropriate secretion of antidiuretic hormone. American Journal of Medicine, 42, 790.

Moses, A.M. \& Miller, M. (1974) Drug-induced dilutional hyponatremia. New England Journal of Medicine, 291, 1234. 